\title{
Final report of IGCP-637: a project linking researchers and heritage stones from around the world
}

\author{
Department of Geology, University of Salamanca, 37008 Salamanca Spain; *Corresponding author, E-mail: mdp@usal.es
}

(Received: August 30, 2020; Revised accepted: September 17, 2020)

https://doi.org/10.18814/epiiugs/2020/020086

\section{Introduction}

The IGCP-637 project on Heritage Stone designation was approved by UNESCO and the International Union of Geological Sciences (IUGS) in 2015 and ended in 2019. The main objective was to facilitate the development of a new International Standard for building and ornamental stones. This was achieved by building an extensive international network of collaborating researchers and publications to extend knowledge on internationally important Heritage Stones. The final report is presented in this paper.

\section{Background}

An informal Working Group on Building Stones and Ornamental Stones was convened at the 33 rd International Geological Congress in Oslo, Norway, in 2008, by a small group of researchers: Barry Cooper (Australia), Björn Schouenborg (Sweden), Brian R. Marker (UK) and Lola Pereira (Spain). The IUGS later granted the status as a Heritage Stone Task Group which aimed to identify the architectural and cultural important stones for which future supplies are needed for maintenance and repair of historic buildings and structures and designate them as Global Heritage Stone Resources (GHSRs). This status was upgraded by IUGS to a Sub-commission (HSS) in 2016. Subsequently, the group has achieved many goals, but probably the most important was to work on the UNESCO-IUGS IGCP-637 project. Over five years (2015-2019) we have spread knowledge on stones of important heritage significance in many countries. This will help in securing the safeguarding of, often localised, outcrops that have sometimes been concealed by careless anthropic actions or could be in danger of being sterilised by future development.

Important activities of IGCP-637 included outreach initiatives to inform non-experts about the significance of Heritage Stones and convince them of the need to safeguard resources for the continuing maintenance and repair of historic buildings and structures, including those in UNESCO World Heritage Sites. Another was to identify important stones that had previously only been described in obscure literature, sometimes in languages that are not widely understood internationally, and to publish readily accessible information on those rocks in high impact factor international journals.
The work of the HSS is disseminated through a website which was updated frequently by the HSS Secretary General: http://globalheritagestone.com/. It makes information available, not only on the stones that the HSS worked on but also other relevant publications, conferences and gatherings. Many researchers learned of the existence of this activity through the website and joined the Sub-commission. The website has a specific page dedicated to IGCP-637 activities and achievements. By the end of the project 121 researchers from 27 countries had actively collaborated in the work (Fig. 1); (Table 1).

Sadly, during the project, we also lost four of our most appreciated colleagues along the way: Anders Wikström, Hannu Luodes, Vladimir Gavrilenko and Don W. Byerly. As former HSS Secretary General, I want to thank them for their support and collaboration even though they are no longer with us.

\section{Global Heritage Stone Resources: Scientific Achieve- ments}

A scientific goal of the IGCP project was to highlight stones that had been used to build monuments and historical buildings of heritage importance over the centuries. Some were already very well known internationally, but others were not. Many lacked full characterization of mineralogy, physical and mechanical properties and many other geological parameters, including the geological settings of their outcrops, in one place. Some stones had been described previously only in obscure literature. A purpose, therefore, was to make information on these widely available to the large academic and professional communities working on natural stones and/or heritage structures built with stone.

By the end of IGCP-637, 22 natural stones had been designated as Global Heritage Stone Resources (GHSRs) and ratified by the IUGS Executive following publication of details in highly recognized journals, especially Episodes, the flagship publication of IUGS. The designated stones are listed in Table 2.

\section{Congresses, Conferences and Workshops}

A general goal of IGCP-637 was to disseminate the work on Heritage Stones to interested researchers and to broaden networks. IGCP- 
Table 1. Countries actively collaborating in IGCP-637

\begin{tabular}{cccc}
\hline \hline Argentina & France & Malawi & Slovenia \\
\hline Australia & Germany & Malta & South Africa \\
Austria & Greece & Netherlands & Spain \\
Belgium & India & Norway & Sweden \\
Brazil & Ireland & Portugal & UK \\
Canada & Italy & Romania & USA \\
Finland & Japan & Russia & \\
\hline
\end{tabular}

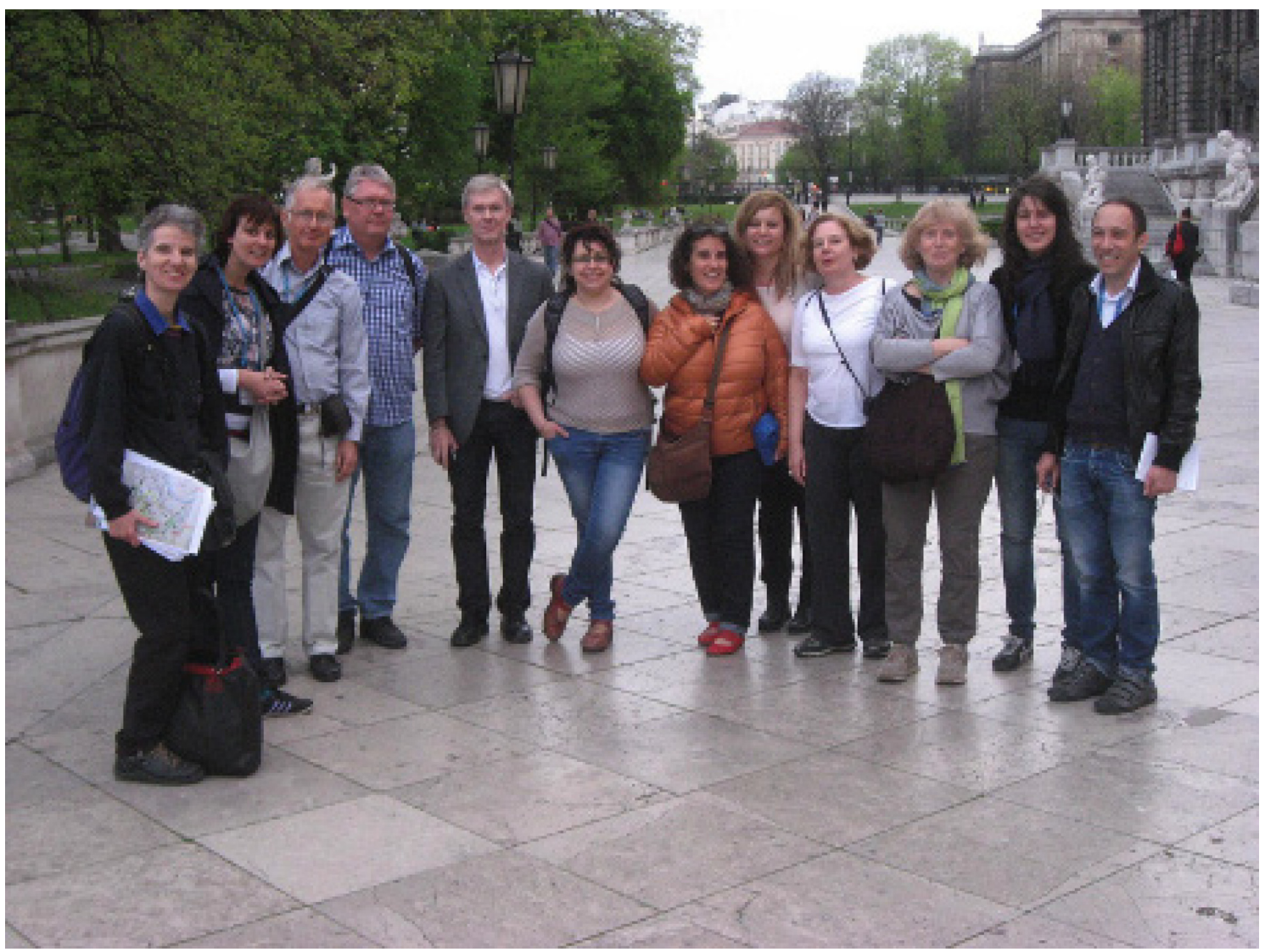

Figure 1. Leading members of IGCP-637 on the first year of the project, in Vienna, 2015.

637 sessions on "Natural stone research and Heritage stone designation" were organised at each annual General Assembly of the European Geoscience Union in Vienna, Austria, since 2015 (EGU-2015, EGU-2016, EGU-2017, EGU-2018, and EGU-2019).

IGCP-637 was also represented at The North Central Section meeting of the Geological Society of America held, in Madison, Wisconsin, USA, 19-20 May 2015, in a session entitled "Cultural Geology and Geo-archaeology: Millstones, Dimension Stones, Capitol Buildings, Heritage Stone, and More".

Lola Pereira gave an invited presentation on heritage stone to the International Congress: "Geoheritage Inventories: Challenges, Achievements and Perspectives" held at the Muséum de Toulouse, 22-26 September 2015.

The first major dimension stone / heritage stone conference in North America was held as a session at the Annual Meeting of Geological
Society of America in Baltimore, Maryland, 1-4 November 2015 under the title "Dimension stone and heritage stone: Quarries, building stones, monuments, sculpture, utilitarian stones and more". In addition, there were three field excursions including tours of Baltimore City and Washington DC, as well as a visit to an active local stone quarry in Cockeysville Marble.

IGCP-637 was also present at the 34th International Geological Congress held in Brisbane, Australia (2012) and at the 35th International Geological Congress held in Cape Town, South Africa (2016), organising symposia dedicated to "Dimension stone and building materials".

A Global Stone Congress, linked to the international stone industry, took place in Bahia, Brazil (26-29 of April, 2018). Some IGCP-637 participants were invited as speakers and IGCP-637 funding helped some early career researchers to pay their registration fees.

In 2018 there was the first thematic workshop on Heritage Stones, 
Table 2. Designated GHSR's by the end of IGCP-637. http://globalheritagestone.com/other-projects/ghsr/designations/

\begin{tabular}{lll}
\hline \hline Name of the designated stone & Country of origin & Publications of reference \\
\hline Portland Stone & England & Hughes et al., 2013 \\
Larvikite & Norway & Heldal et al., 2015 \\
Petit granit & Belgium & Pereira et al., 2015a \\
Hallandia gneiss & Sweden & Schouenborg et al., 2015 \\
Podpêc limestone & Slovenia & Kramar et al., 2015 \\
Carrara marble & Italy & Primavori, 2015 \\
Estremoz marble & Portugal & Lopes and Martins, 2015 \\
Villamayor stone & Spain & Garcia-Talegón et al., 2015 \\
Lede stone & Belgium & De Kock et al., 2015 \\
Welsh slate & United Kingdom & Hughes et al., 2016 \\
Piedra Mar del Plata & Argentina & Cravero et al., 2015 \\
Kolmården serpentine marble & Sweden & Pereira and Wikström, 2015 \\
Lioz stone & Portugal & Silva, 2017 \\
Jacobsville sandstone & USA & Rose et al., 2017 \\
Maltese Lower Globigerina Limestone & Malta & Cassar et al., 2017 \\
Alpedrete Granite & Spain & Freire-Lista et al., 2015 \\
Bath Stone & United Kingdom & Marker, 2015 \\
Macael Marble & Spain & Navarro et al., 2017 \\
Makrana Marble & India & Garg et al., 2019 \\
Pietra Serena & Italy & Fratini et al., 2015 \\
Rosa Beta Granite & Italy & Careddu and Grillo, 2015 \\
Tennessee "Marble" & United States of America & Byerly and Knowles, 2017 \\
\hline
\end{tabular}

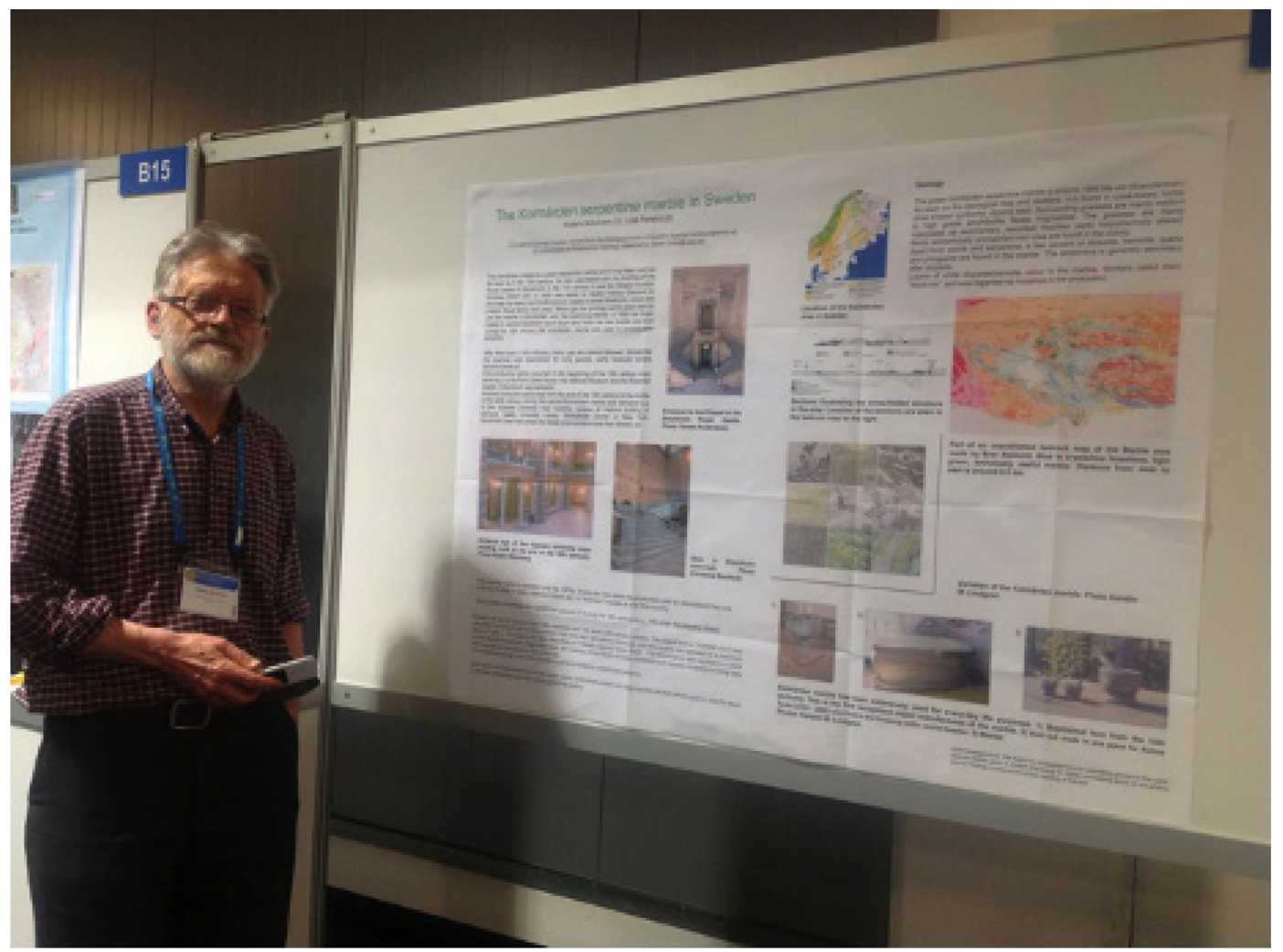

Figure 2. Anders Wikström presenting the Kolmården serpentine marble at EGU 2015. This stone was designated GHSR.

celebrated under the umbrella of IGCP-637: 1st Workshop on Heritage Stones (2-4 of October, 2018), Salamanca, Spain. The proceedings were published online (https://issuu.com/home/published/compilacion_ab- stract reducido) and the IGCP-637 team issued their first poster, as a "roll-up" (Fig. 3). Because of the recent recognition by IUGS of Villamayor sandstone as a GHSR the poster was presented to the mayor of 


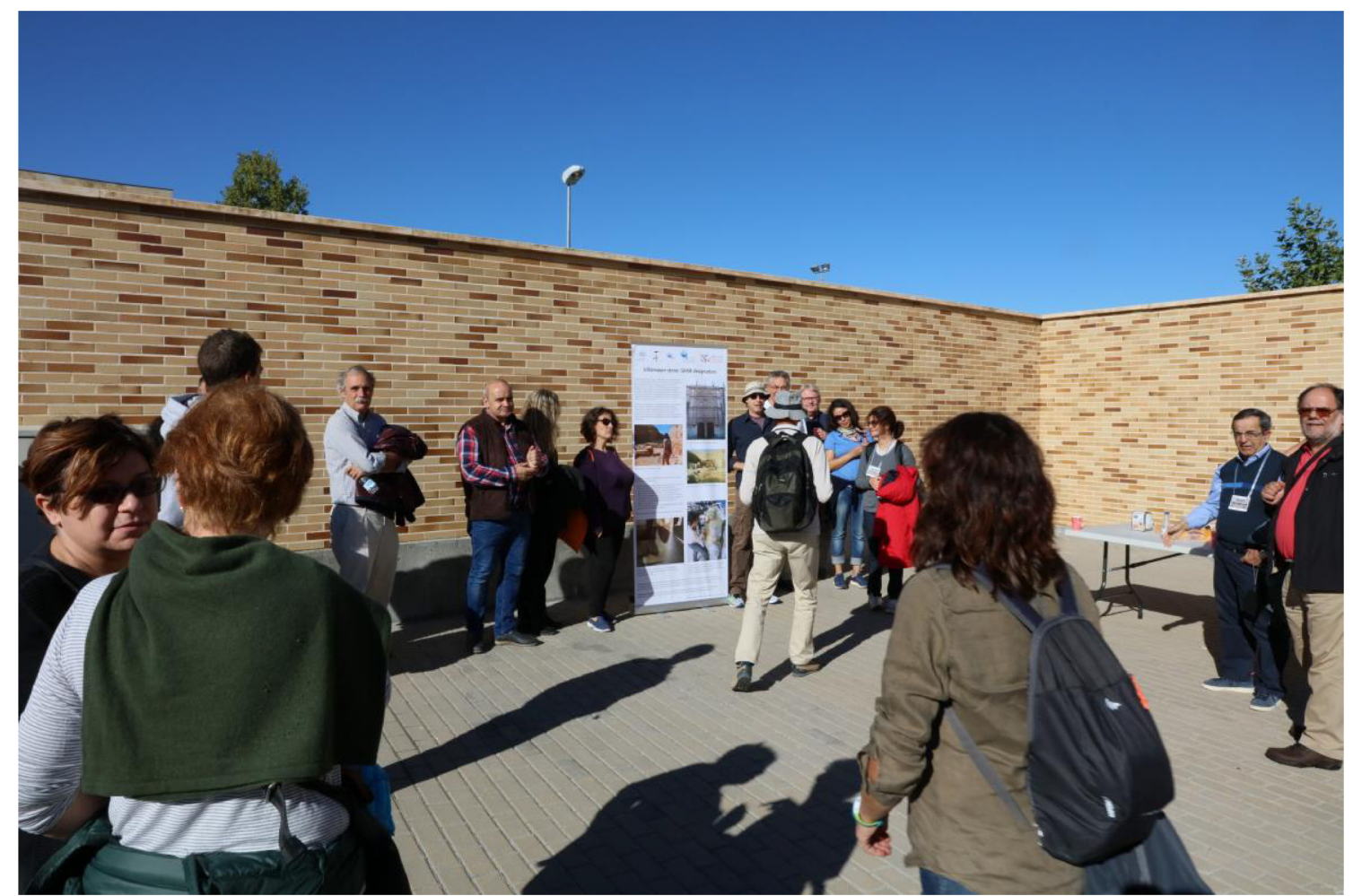

Figure 3. Field excursion to the historical quarry of Villamayor and presentation of the poster describing the GHSR designation of Villamayor sandstone to the Mayor of the City.

the city of Villamayor and now hangs as an object of pride at the City Council building. This highlights the importance of IGCP support for heritage stone work in achieving public communication benefits.

Unfortunately, the project session organised for the $36^{\text {th }}$ IGC in Delhi had to be cancelled due to COVID-19. We had intended to present the final achievements of IGCP-637 in a poster which is presented here instead (Fig. 4).

\section{Networking}

Extending the international Heritage Stones network was one of the most useful outcomes of IGCP-637 funding. We were able to extend the network, both in numbers of correspondents and geographical extent, bringing in the participation of scientists from developing countries, and in particular young and women scientists. Several female researchers and young researchers from developing countries had their expenses partially covered to attend the international meetings organized under the umbrella of IGCP-637. Those countries were Malawi, Algeria, India, Brazil, Morocco, Argentina, and Malta (Table 3).

\section{Publications and Outreach}

More than 70 articles have been published from IGCP-637 activities; some in books and others as individual papers or in Special Issues of highly cited journals. The first major publication from the IGCP project was a Special Publication of the Geological Society, London (Pereira et al., 2015b). It contained 22 papers in 275 pages. Two more books containing papers have been published subsequently (Kato et al.,
2016 and Pereira et al., 2018). Others are planned. In addition a book was published on stones of Salamanca, Spain (Pereira et al., 2018). An important new departure was the initiation of a series of books under the general title "Natural Stone and World Heritage" by Taylor and Francis. The first considered the World Heritage Site of Salamanca (Pereira, 2018) and the second considered stones of Delhi and Agra, India (Kaur et al., 2020).

There have been five special issues of journals (Pereira and Pratt, 2016; Pereira et al., 2015c, Pereira et al., 2019; Pereira and Cárdenes, 2019 and Kaur et al. (in press)).

A review of Heritage Stone activities was requested by the journal Geosciences (Pereira and Marker, 2016). This paper has been downloaded from the journal page 2,423 times and has been cited 18 times, helping to promote general awareness of the working group and also the aims of IGCP.

Outreach activities through social media (Face book, Twitter and YouTube) have been a useful tool for dissemination of project achievements. Other media have also been used e.g. the online Global Magazine for Architecture, Art and Design with Natural Stone published an article summarising the achievements of the project.

https://www.stone-ideas.com/64790/global-heritage-stone-resourceghsr/

\section{Conclusions}

During the five years that IGCP-637 was active, many achievements have been made while also promoting IUGS Heritage Stones Sub- 


\section{(遖) Thex \\ IGCP-637 Heritage Stone Designation: A succesful UNESCO and IUGS project on natural stones.}

Dolores Pereira [1), Gurmeet Kaur (2)

(1) Universid ad de Salamanca, Department of Geology, Spain (mdp@usal.es)
(2) Department of Geology, Panjab university, chan digarh, India (gurmeet28374@gmail.com

IGCP Project 637 was approved in 2015 to facilitate establishment of a new international geological standard for building and ornamental stones. Formal international recognition of those natural stone types that have achieved widespread utilisation in human culture is now underway and the term "Global Heritage Stone Resource" (GHSR) has been proposed for this designation. Where appropriate a "Global Heritage Stone Province" (GHSP) embracing several heritage stones $\mathrm{may}$ also be defined. Stones that have been used in heritage construction, sculptural masterpieces, as well as in utilitarian (yet culturally important) applications are obvious GHSR candidates. In furthering these aims, the project has promoted the adoption and use of the GHSR designation. Consequently an interim list of potential GHSRs is maintained and a register of GHSR approved stones has

Achievements:

22 well known stones have gone through the whole evaluation procedure and are now ficially designated:

\section{Portland Stone from Uk}

Pettl granlt from Bel gegum

Podpéc Ilmestone from Slover

Carrara Marble, from Italy

Hallandla Gnelss, from Sweden

Mlllam ayor Stone from Spaln

Lede Stone from Belglum

Pledra Mar del Plata from Argentina

Welsh Slate from uK

Lloz Umestone from Portugal

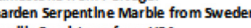

Jacobsville Sandstone from USA

Makrana marble from Indla

Rosa Beta Granlte from italy

Alpedrete granite form Spaln Tenesse "marble" from USA Bath Stone from UK

Pletra Serena from italy
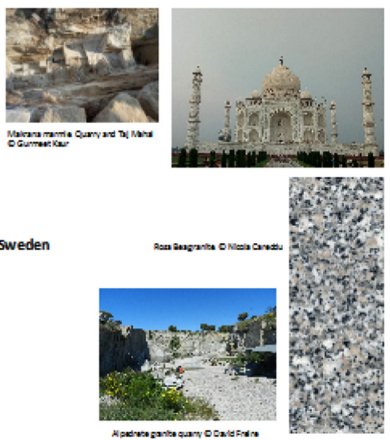

Publlcations supported by IGCP-637:

- Pereira, D. et al, 2015. G lobal Heritage Stone: Towards International Recognition of Building and Ornamental Stones Geological; Society of London, Special Publication 407, 275pp.

- Pereira, D. et al. 2015. Special Issue: Glo bal Henitage Stone Resource: An Update. Episodes 38 (2). 43: 3-8B.

43: $3-88$.

Pereira, D. \& cár

Group.
Pereira, D. et al. 2019. Natural Stone and architectural herit age. Sustain abiilty. MDPI.

Kaur, G. et. al. 2020. Natural Stone and World Heritage: Delhi-Agra, India CRC Press, Tayior \& Francis Group.

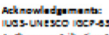

The procedure to achieve the GHSR can be found at www.globalheritagestone.com

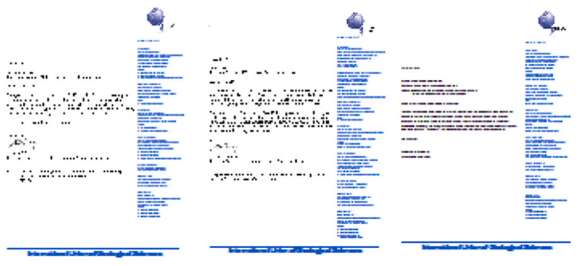

IGCP funding has been mostly used to cover expenses of researchers to participate in the meetings organized or co-organized by the Heritage or funding are early scientists and researchers from low income countries. So far, scientists from Malawi, Spain, Algeria, Italy, India, Morocco, Russia, Brazil, Argentina, Rumania and Slovenia have received some funding to partly cover their travelling expenses. Reports and contributions from all these have been publishedin a number of 5 pegal
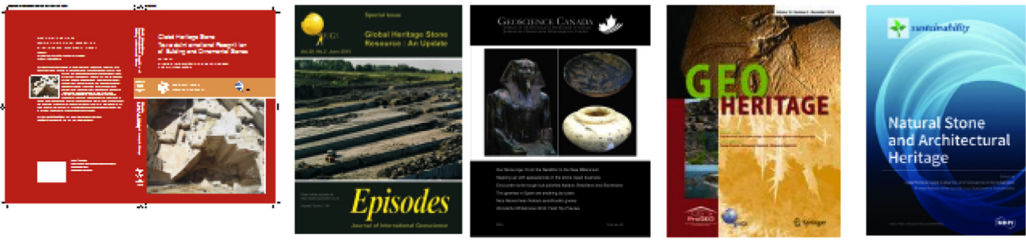

The last publication initiative has to do with a Book Series on Heritage Stone and World Heritage. This is a series of short books on specialized topics that fall under the overarching theme of geological and cultural heritage of stone, the built environment, and the geological and engineering characteristics of the dimension and ornamental stones. The books deal with well documented case studies of construction and restoration works at one or more

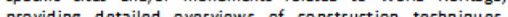
documentation of the materias utilined during the historisal period which the monuments were buitt and specific conservation preservation works that have been carried out The books hishlight the importance of natural stone in the preservation of cultural heritage in a sustainable way: moreover, natural stones (heritage stones) often represent the tangible trace of culture development in specific areas, including important activities like quarrying.

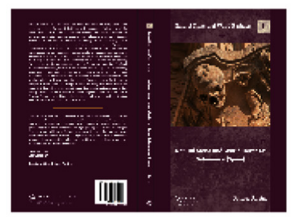

The books are closely linked to UNESCO World Heritage sites around the world. After Salamanca and Delhi, another 10 books will follow: Rio de laneiro, Edinburgh, Germany, Ljubljana, Slovenia, Madrid, Florence, Apulia region, Philippines, North Wales an Western Alps, Italy

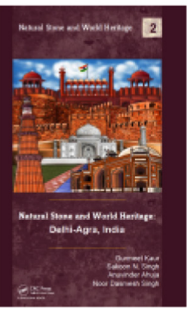

Figure 4. Poster summarising final IGCP-637 achievements.

Table 3. Numbers of scientists attending the four events (years 2016, 2017, 2018 and 2019) organized within IGCP-657. Most scientists from developing countries attending (bottom row) were partly funded by the project

\begin{tabular}{cccc}
\hline \hline & Total number of scientists & Number of male scientists & Number of female scientists \\
\hline Numbers of participating scientists & $35+27+49+19=130$ & $22+17+25+8=72$ & $13+10+24+11=58$ \\
Numbers of young scientists/students ( $<35$ years old) & $5+6+11+8=31$ & $2+3+6+5=16$ & $3+3+5+3=14$ \\
Numbers of scientists from developing countries & $5+3+7+8=23$ & $2+1+3+4=10$ & $3+2+4+4=13$ \\
\hline
\end{tabular}

commission. Natural stones that were previously described in obscure publications are now reflected in widely available international literature. Many researchers, including young researchers, female researchers and researchers from low-income countries are now part of the natural stone community, thanks to the IGCP program. Stones that have played an important part in architectural and cultural heritage have started to be recognized by IUGS as a geological standard, the Global Heritage Stone Resource.

With this project we have also provided the information of the need of proper characterization of stones to promote their use in construction and restoration. Comprehensive information is now stored in the HSS web page, but also in the journals that published the outputs, mainly those related to IUGS: the journal Episodes and the Geologi- cal Society of London Special Publications. Also proceedings and media reports are now uploaded in the IGCP-637 section of the HSS webpage.

Many articles have been generated for technical journals and local papers. Leaders of the project have been interviewed about heritage stones and related projects by local newspapers and academic media aiming a wider diffusion. A video was recorded at the University of Salamanca with information about the IGCP-637: https://www.facebook.com/watch/? $\mathrm{v}=409940296094718$. The HSS planned a workshop on Heritage Stones to be held in March 2020 at the $36^{\text {th }}$ IGC but, due to COVID-19, this and other IGCP activities have been postponed. However the information from the intended session will be published in different media. 


\section{The future}

IGCP-637 has been a very successful initiative and will now continue: an extension was approved in 2020: http://www.unesco.org/new/en/ natural-sciences/environment/earth-sciences/international-geoscienceprogramme/igcp-projects/earth-resources/igcp-637/.

\section{Acknowledgements}

This Project could not have succeeded without the support of researchers, correspondents, reviewers, editors, guest-editors and conveners of meetings who are too many to list but all deserve sincere thanks. Brian Marker is acknowledged for his great help, not only reviewing this report, but for his support at all times.

\section{References}

Byerly, D.W., and Knowles, S.W., 2017, Tennessee "Marble": A Potential Global Heritage Stone Resource. Episodes, v. 40-4, pp. 325-331

Careddu, N., and Grillo, S., 2015, Rosa Beta granite (Sardinian Pink Granite): a heritage stone of international significance from Italy. Geological Society Special Publications, v. 407, pp. 155-172.

Cassar, J., Torpiano, A., Zammit, T., and Micallef, A., 2017, Proposal for the nomination of Lower Globigerina Limestone of the Maltese Islands as a "Global Heritage Stone Resource", Episodes, v. 40-3, pp. 221-231.

Cravero, F.M., Ponce,B., Gozalvez, M.R., and Marfil, S.A., 2015, 'Piedra Mar del Plata': An Argentine orthoquartzite worthy of being considered as a 'Global Heritage Stone Resource'. Geological Society Special Publications, v. 407, pp. 263-268.

De Kock, Boone, T.M., Dewanckele, J., De Ceukelaire, M., and Cnudde, V., 2015, Lede Stone: A potential "Global Heritage Stone Resource from Belgium. Episodes, v. 38, pp. 91-96.

Fratini, F., Pecchioni, E., Cantisani, E., Rescic, S., and Vettori, S., 2015, Pietra Serena: the stone of the Renaissance. Geological Society Special Publications, v. 407, pp. 173-186.

Freire-Lista, D., Fort, R., and Varas-Muriel, M.J., 2015, Alpedrete granite (Spain). A nomination for the "Global Heritage Stone Resource designation. Episodes, v. 38, pp. 107-113.

Garcia-Talegón, J., Iñigo, A. C., Alonso-Gavilán, G., and Vicente-Tavera, S., 2015, Villamayor Stone (Golden Stone) as a Global Heritage Stone Resource from Salamanca (NW of Spain). Geological Society Special Publications, v. 407, pp. 109-120.

Garg, S., Kaur, P., Pandit, M.K. Fareeduddin, Kaur, G., Kamboj, A., and Thakur, S.N., 2019, Makrana Marble: a Popular Heritage Stone Resource from NW India. Geoheritage, v. 11, pp. 909-925.

Heldal, T., Meyer, G. B., and Dahl, R., 2015, Global stone heritage: Larvikite, Norway. Geological Society Special Publications, v. 407, pp. 21-34.

Hughes, T., Lott, G.K., Poultney, M.J., and Cooper, B.J., 2013, Portland Stone: a nomination for "Global Heritage Stone Resource" from the United Kingdom. Episodes, v. 36, pp. 221-226.

Hughes, T., Horak, J., Lott, G., and Roberts, D., 2016, Cambrian age Welsh slate: a global heritage stone resource from the United Kingdom. Episodes, v. 39, pp. 45-51.

Kato, H., Shimazaki, Y., and Reedman, A., 2016, Stone Heritage of East and Southeast Asia. Geological Survey of Japan (GSJ)-CCOP (eds). $234 \mathrm{p}$.

Kaur, G., Frascá, H., and Pereira, D., in press, Heritage Stones. A step forward. Episodes, v. 44, pp. 1-80.

Kaur, G., Singh, S.N., Ahuja, A., and Singh, N.D., 2020, Heritage Stone and World Heritage: Delhi-Agra (India). CRC Press. Taylor and Francis Group. 186 p.

Kramar, S., Bedjanič, M., Mirtič, B., Mladenović, A., Rožič, B., Skaberne, D. Gutman, M., Zupančič, N., and Cooper, B., 2015, Podpeč limestone: a heritage stone from Slovenia. Geological Society Special Publications, v. 407, pp. 219-232.

Lopes, L., and Martins, R., 2015, Global Heritage Stone: Estremoz Marbles, Portugal. Geological Society Special Publications, v. 407, pp. 57-74.

Marker, B.R., 2015, Bath Stone and Purbeck Stone: A comparison in terms of criteria for Global Heritage Stone Resource Designation. Episodes, v. 38, pp. 118-123.

Navarro, R., Pereira, D., Cruz, A.S., and Carrillo, G., 2017, The Significance of "White Macael" Marble Since Ancient Times: Characteristics of a Candidate as Global Heritage Stone Resource. Geoheritage, v. 11, pp. 113-123.

Pereira, D., and Wikström, A., 2015, The Kolmården serpentine marble in Sweden: a stone found both in castles and people's homes. Geological Society Special Publications, v. 407, pp. 48-56.

Pereira, D., Marker, B.R., Kramar, S., Cooper, B., and Schouenborg, B., 2015, Global Heritage Stone: Towards International Recognition of Building and Ornamental Stones. Geological Society, London, Special Publications, v. 407, pp. 1-4.

Pereira' D., Tourneur, F., Bernáldez, L., and García Blázquez, A., 2015, Petit Granit: A Belgian limestone used in heritage, construction and sculpture. Episodes, v. 38, pp. 85-90.

Pereira, D., and Marker, B.R., 2016, The value of original natural stone in the context of architectural heritage. Geosciences, v. 6, pp. $1-9$.

Pereira, D., and Pratt, B.R., 2016, Heritage Stones of the World: Introduction to the New Series. Geoscience Canada, v. 43, pp. 3-4.

Pereira, D., 2018, Natural Stone and World Heritage: Salamanca, Spain. CRC Press. Taylor and Francis Group, $116 \mathrm{p}$.

Pereira, D., Gonzalez Neila, C., and del Arco, A., 2018, Salamanca: city of Stone and Heritage: https://www.libreriaproteo.com/libro/ver/2297022salamanca-ciudad-de-piedra-y-patrimonio.html, $80 \mathrm{p}$.

Pereira, D., Catarino, L., and Dino, G.A., 2019, Natural Stone and Architectural Heritage. Sustainability, v. 11-15.

Pereira, D., and Cárdenes, V., 2019, Heritage Stones and Geoheritage. Geoheritage, v. 11, pp. 1-2.

Primavori, P., 2015, Carrara Marble: a nomination for 'Global Heritage Stone Resource' from Italy. Geological Society Special Publications, v. 407, pp. 137-154.

Rose, W.I., Vye, E.C, Stein, C.A., Malone, D.H., Craddock, J.P., and Stein, S.A., 2017, Jacobsville sandstone: A candidate for nomination for "Global Heritage Stone Resource" from Michigan, USA. Episodes, v. 40, pp. 213-219.

Schouenborg, B., Andersson, J., Göransson, M., and Lundqvist, I., 2015, The Hallandia gneiss, a Swedish heritage stone resource. Geological Society Special Publications, v. 407, pp. 35-48.

Silva, Z.C.G., 2017, Lioz: a Royal Stone in Portugal and a Monumental Stone in Colonial Brazil. Geoheritage, v. 11, pp. 165-175.

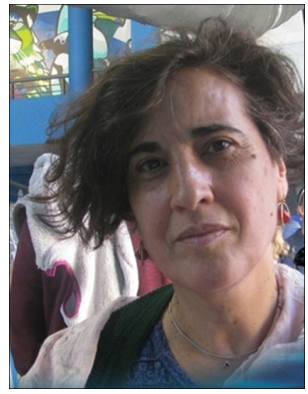

Dolores Pereira is professor of Geology and Engineering Geology at the University of Salamanca. She teaches as well at the Master of Social Studies for Science and Technology of this university. She is secretary general of the IUGS Heritage Stones Subcommission and Chair of the IUGS Publications Committee. Her research interests include natural stones from their chemical, mineralogical, hazardsrelated matters and physic-mechanical characterization point of view as well as their use in new building and restoration of architectural heritage. 